Sergej Flere ${ }^{1}$

University of Maribor

Faculty of Philosophy

Maribor (Slovenia)
UDC 94(497.1)"1943"

Original scientific paper

Submitted 06/11/2018

Revised 29/12/2018

Accepted 08/01/2019

doi: 10.5937/socpreg52-19443

\title{
THE AUTHENTICITY OF THE FOUNDING OF TITO'S YUGOSLAVIA AS A FEDERATION
}

Abstract: It is widely accepted that Tito's Yugoslavia was institutionally founded at AVNOJ, namely the Second Session of the Anti-Fascist Council of National Liberation of Yugoslavia, held on November 29, 1943 in Bosnian woods. At the assembly, a Decree concerning the federal organization was to be adopted. The Decree contained principles of Yugoslavia's future organization (six republics, along with the parity of republics and nationalities). Neither scholars nor politicians, in the former country and abroad, have questioned the veracity of the assertion that the Decree was adopted at this Session.

The Decree was instrumental in the communist drive to impose a federation and communism, when confronted with pre-war politicians in the Transitional and Constitutional Assemblies, in 1945 and 1946. The communists were able to claim that federalism had already been instituted. Later, the Decree was widely invoked during Tito's Yugoslavia, both by those who advocated greater "states' rights" and by those claiming that Yugoslavia was already too decentralized.

On closer inspection, it is more than questionable whether such constitutional Decree could have been adopted in such a situation. Many issues the decree governs were matters of contention and final decision making within AVNOJ after the Second Session (and in 1945). Technicalities also point to the Decree not being adopted at that moment, but in an informal situation by the communist leaders at a later date, however, not later than February 1945. Nevertheless, the Decree widely functioned as a source of legitimacy and an instrument for setting certain limits in the political life of the former state.

Keywords: Anti-Fascist Council of National Liberation of Yugoslavia (AVNOJ), Josip Broz Tito, ehnicity, communism.

\section{Historical introduction}

From the very beginning of the Yugoslav Partisan movement in 1941, led by communists, Tito and probably others had the idea of laying down a basis of civil support in some institutional way. This was to pave the way for the future form of government, a

1 sergej.flere@um.si 
communist federation. As early as in August 1941, Tito pondered on a "National Liberation Committee" in a letter to the leaders of the Croatian Partisans, Rade Končar and Vladimir Popović (Petranović, 1988, II, p. 197), This was implemented first at the local level, although already in 1942 there was an attempt by the Anti-Fascist Council of National Liberation of Yugoslavia (known by the Serbo-Croat acronym AVNOJ) to hold a "parliament”. Veselin Masleša, a leading Bosnian communist, stated it was "not elected technically...but more democratically than any thus far representative body in Yugoslavia" (Pijade and Nešović, 1973, p. 36). Its significance was limited, since Slovenes, beside Macedonians and delegates from Kosovo, were not present. It was composed of Partisan leaders and supporters.

After September 1943, when Italy departed from the Axis forces, the Partisan movement gathered further momentum, by forced call-up included. German forces were not able to replace the Italian ones, giving the Partisan forces impetus, particularly in the Western parts of Yugoslavia. Even in Macedonia (where previously no Yugoslav-oriented initiative could gain popular support), a Partisan movement arose. Tito's emissary to the South at the time endeavored to get the Albanians to join the Partisan forces (Petranović, 1991). The Partisans began to act as an official force (although styling itself as the Yugoslav Army would come later).

Military wise, at the time, a British intervention in Yugoslavia would also have been possible, which would have raised the possibility of reestablishing the old regime, although it is almost impossible that Yugoslavia would have been reestablished as a lasting state in such a manner. Relations within the government in exile give evidence in this direction because of the bitter squabbling and inability to operate (Pavlowitch, 2008, p. 190; Petranović, 1990, pp. 506-520). Hobsbawm, Pavlowitch and Banac all agree on the communists being the only ones able to renew Yugoslavia (Hobsbawm, 2010, p. 82; Pavlowitch 2008, p. 280; Banac, 2009).

Towards the end of 1943, the Partisans were far from prevailing in the military control over the territory; The Nazis and their Quislings were dominant throughout Yugoslavia. The Partisans themselves were far from being a compact force (Nikolić, 2015), although there was a central command headed by Tito, and there were central units as well, in contrast to the local ones, the members of which would not have been ready to depart far from their respective localities. This was true particularly for the Slovenes. Hebrang, the sovereign leader of the Croatian Partisans, constantly emphasized the Croatian nature of the movement and criticized the rotten nature of Yugoslavia as such in its publications, although Serbs formed the majority of his forces until the end of 1943. In Serbia proper, after the debacle of the 1941 "Republic of Užice" (a territory in south-western Serbia liberated for 70 days) and after brutal mass German reprisals, the Partisan movement in Serbia was weak, making the political position of Serbian communist leaders Žujović, Nešković and Pijade also weak.

In Vojvodina (with the exception of Srem/Syrmia, whose Partisans were associated with those in Bosnia), the Partisan movement was also weak. Partisans operated mostly by way of physically underground "bases". In Kosovo, it was mostly allied to the Albanian Partisan movement with a view to unify with them. The national enmity prevented the establishment of joint Serbian-Albanian forces, although there were attempts. In Macedonia, the Partisans were motivated mainly by the dream of a »Greater Macedonia« (Nikolić, 2015). 
In this paper, the circumstances of the Second Session of AVNOJ, the adoption, dating and relevance of the document to the future federal organization of Yugoslavia will be dealt with.

Even before the session began, important discussions were held. Đilas reported that the Serbian leaders, Žujović, Pijade and others promoted the idea of doing away with the monarchy; since monarchy was most popular in Serbia, the absence of monarchy would make the situation for their future rule more facile (Đilas, 1994, p. 43). Other participants were more reserved on this issue, as they were aware that an adverse reaction would come from the Western allies and from the Soviet Union.

A Croatian politician Božidar Magovac, the Croatian Peasant Party leader, was to have mentioned organizing Yugoslavia as a confederation (Mršić, 1992, pp. 262-5). This indicates a variety of ideas circulating in Jajce prior to the Session. Among communist leaders at the time of the Second Session, there were particular disputes as to what the federation should be like (if at all):

* Moša Pijade promoted the idea of an autonomous Serbian unit in Croatia (probably in agreement with Nešković ${ }^{2}$ and Žujović, leaders of the Communist Party [CP] in Ser$\mathrm{bia}^{3}$, who would not themselves have dared to make such proposals), which was rejected by Đilas and Tito;

* Slovenes expressed their separateness and insistence that Slovene units would not intervene outside Slovenia; they insisted on the Slovene language as the sole language of command, which Tito had confirmed to the Slovene delegation at the Second Session for the future. Slovenes may have been most enthused at the Second Session for having become a "historical nation" and "taking their history into their own hands", as Josip Vidmar claimed at the session, but Lola Ribar, the leader of the communist youth organization (SKOJ), accused the Slovene Partisans of "separatism" as early as April 19434 (Documents, 1981, p. 228),

* Albanian communists from Kosovo and elsewhere accepted command primarily from the communist leadership in Albania and associated with Albanian rightist organizations, all dreaming of a "Greater Albania" as something conceivable (Petranović, 1991),

* The Croatian communist leader Andrija Hebrang was completely independent, claiming not only Baranja, but also Srem, and organizing Croatian communist cells in Bosnian towns, dreaming of a "national state" (Bilandžić, 2006, p. 447),

* In Macedonia the situation was not articulate; the Partisan movement was weak and dreaming of a "Greater Macedonia". Tito needed to send numerous emissaries. Anti-Yugoslav disposition was so strong that »any mention of Yugoslavia makes the mobilization of Macedonian masses impossible« reported earlier by Dobrivoje Radisavljević (Vujošević, 1988, pp. 422-423),

${ }^{2}$ Nešković was exeplled from the CP in 1952 for, among other things, "Greater Serbian chauvinism" (Nikolić, 2015, p. 480). Nikolić also relates this to Nešković’s opposition in 1945 to Kosovo being granted autonomy.

${ }^{3}$ Even Jovan Veselinov, one of the leading Serbian communists in the post-war period is presumed to have said late in his life that Nešković and Pijade were "ardent Serbian nationalists" (Popović, 2006, III, p. 30).

${ }^{4}$ Even in 1945, the Slovene command refused intervention in neighbouring Lika by the then General Staff of the Yugoslav Army (Križnar, 1987, p. 355). However, in 1945, Slovene forces lost their autonomy and became part of the Yugoslav Army. 
* Partisan movements in Bosnia and Herzegovina and in Sandžak, unexpectedly for some, organized their "land councils" at variance with the communist teaching on national self-determination, since these two regions were multi-ethnic. In both cases, the essence was the protection of Bosniaks/Muslims (Petranović, 1990, pp. 565, 567),

* Serbian communist leaders could not be forceful as they would be under the burden of the idiom of "Serbian hegemony"). They also could, however, not be satisfied with the "emancipation" of Sandžak, Bosnia and Herzegovina, Macedonia, Vojvodina and Montenegro.

This picture may be supplemented with the situation in the government in exile in London, where ethnic dispute also prevailed, but only Serbs, Croats and Slovenes "counted" in that theatre. Supplementing the three, thus, could add a new balance to the relationship.

Đilas later wrote that communist regimes went corrupt by rise of nationalism (Đilas, 1994), but there was enough nationalism at the beginning in this case, although it does not mean there was no space for further national »maturation «. We are hence confronted with a coalition of nationalist movements, not communist in substance, but in form, mastered and suppressed in their extreme variants particularly by Tito himself, with the help of Đilas, with Kardelj also being instrumental in this respect at the time.

\section{The Session}

On the course of the Second Session, we are informed through an official presentation given by Pijade and Nešović (1973). The presentation was heavily edited, although the meeting was stenographed. Some speeches were not presented in entirety (with ellipses indicating incompleteness), so we are not sure everything was being reported. Although Žujović's speech was given, it seems that Hebrang did not speak, although present, which is hard to believe. The stenograph is not to be found in the Archives of Yugoslavia, Serbia, Slovenia or Bosnia and Herzegovina, and was probably discarded after the publication of the book edited by Pijade and Nešović in 1951 (1973).

The official presentation of the Session in the book form given by Pijade and Nešović (1973) is probably correct in its depiction of a high degree of enthusiasm and euphoria present among the delegates. This was confirmed in the many testimonies in a 6-volume book edited by Đorđević and Spasić (1963-1973), including some which can be trusted (in contrast to others which were propaganda-type). At the Session itself, euphoria prevailed, with Ljubo Leontić, an elderly pre-war moderate politician from Croatia, calling the event "miraculous" (Pijade and Nešović, 1973, p. 201).

The Session was opened by its President Ivan Ribar, but the main speech was given by Tito, followed by many major communists and also non-communists. Overall, the session itself was a huge manifestation of enthusiasm and unity, of hope and determination, although the speakers did speak as members of their respective nationalities.

Among the speakers, after Tito's enthusiastic speech, Serbs followed. Aleksandar Ranković "greeted" AVNOJ on behalf of the Communist Party of Yugoslavia, Mitra Mitrović on behalf of the Women's Antifascist Front (AFŽ), while Mihailo Švabić did so on behalf of the Communist Youth (SKOJ). Mijalko Todorović, Serbian political commissar of the First Proletarian Brigade was the only one to offer "national self-criticism". 
He did not mention Serbian hegemony, as some non-Serbs did. He stated that Serbia had been "the center of reaction", which would never happen again. He did say the struggle "developed " in other areas of Yugoslavia, "thanks to the struggle [previously] having developed in Serbia“" (Pijade and Nešović, 1973, p. 162). Thence, Serbs were well represented, but not backed by a national anti-fascist land council.

Moreover, Sreten Žujović, a Serbian communist leader, as if challenging Tito, alleged that Tito would not find in Belgrade, upon liberation, "a bazaar with Greater Serbian bourgeoisie", but that the next AVNOJ session would be held there (Pijade and Nešović, 1973, p. 223). Turning to the Slovene professional military officer Jaka Avšič, he did say that "the Serbian people never ceased fighting" (Pijade and Nešović, 1973, p. 223). Jaka Avšič stated "we, Slovenes, were truly the first to grasp that we were condemned to death" (Pijade and Nešović, 1973, p. 204), a Croatian communist Pavle Gregorić boasted of "Croatian masses throughout Croatia taking part in the Partisan movement and deciding on their fate" (Pijade and Nešović, 1973, p. 228) - although it was actually Serbs who were first to become Partisans in Croatia. Marko Vujačić from Montenegro boasted of Montenegrins being "fighters with greatest resolve" (Pijade and Nešović, 1973, p. 164). Čolaković, possibly the most senior communist, in a short speech mentioned Bosnia and Herzegovina 11 times, including that it would no longer be a "woman-servant" pleading for republic status, without stating so explicitly (Pijade and Nešović, 1973, pp. 220-221). Sulejman Filipović could say only that "Muslims were among the first to condemn the atrocities in 1941 by their resolutions" (Pijade and Nešović, 1973, p. 213). All of them were thus speaking as members of their nations. The national promotional content of what they were speaking is clear, attempting to shed best light on their own respective nations.

The Second Session, lasting one night only, did adopt some undisputed decisions: it proclaimed itself the highest body of authority in Yugoslavia; it established a "National Committee«, a sort of government (presided by Tito); it conferred the title of Marshall upon Tito, and also established a legislative committee which would prepare legislation for subsequent adoption, headed by Moša Pijade (Dedijer et al, 1972; Petranović, 1989). All these resolutions are to be found in the Archives of Yugoslavia on public display (Archives of Yugoslavia, n.d.) The Second Session did not address each nationality of Yugoslavia individually, but all of them together, calling them to join the battle against occupiers and particularly calling men to leave the Quislings (practically, all active military units - and there were many - which were non-Partisan were considered Quislings).

\section{The Decree and its Relevance}

In scientific literature dealing with Tito's communist Yugoslavia, it is often considered that it was established by an almost self-organized parliament, the AVNOJ at its Second Session held on November $29^{\text {th }}, 1943$. There is no dispute over the Council having held three sessions and that during the third one it was transformed into a transitional parliament of Yugoslavia (integrating some pre-war deputies and politicians as a final step), paving the way for convening a communist-organized Constitutional Parliament, which would adopt the (communist federal) Constitution of Yugoslavia on January $31^{\text {st }}, 1946$. It is also not disputable that the Second session was held at Jajce, at the time claimed. 
The Second Session "deputies" met on the night of the 29-30 th November 1943 (Dedijer et al, 1972; Pijade and Nešović,1973). This is beyond dispute, although it was a very difficult and risky undertaking, given that the Nazis were persecuting the Partisans in general (for example, Petranović, 1988, II, pp. 280-302; Ramet, 2006, p. 157).

The Decree on organizing Yugoslavia under the federal principle is usually considered the major achievement of the Session. Most importantly, the Decree provided guarantees on Yugoslavia being composed of six republics, equal in rights and obligations and on the parity of nationalities. It also enumerated the existing "land" civil authorities, existing allegedly. The Decree is deposited in the Archives of Yugoslavia and is composed of two pieces of paper carefully glued together, to fit the entire contents on a single page and stamped by "AVNOJ PRESEDENCY SECRETARIAT, BELGRADE", signed by the AVNOJ President and Secretary. It bears the number 3 among the documents adopted at the Session. However, the catalogue register of documents in the Archives states that this is a rescript, signed in November 1945. Hence, there is no original to be found (Archives of Serbia, Bosnia and Herzegovina, Slovenia and Military Archives were consulted).

It would be very unusual for such a Decree, constitutional in nature, to be adopted in some woods in Bosnia, during a single night, by 'deputies' not elected by ballot. But this is not sufficient to exclude the possibility. There was a rationale why it was later presented as so. It would be difficult to adopt such a decision in »normal times and conditions, as there were many interests, contested issues and doubts. It would be much easier for the communist leaders to dispose of such a document, particularly when faced with »bourgeois« politicians, particularly Serbian ones.

But did they truly adopt the "Decree on Establishment of Yugoslavia under the Federal Principle" on the fateful night, as Yugoslav communist politicians would later hold as a "fact" which later gained general currency? For example, Edvard Kardelj would maintain on August 10, 1945 at the Transitional Parliament, in his capacity of Deputy Prime Minister, that »the decisions of the Second Session are constitutional in nature...Today, Yugoslavia is a federal state (Provisional National Assembly,1945, p. 157), paying lip service to the possibility that the future Constitutional Parliament could change it. He also commented the Decree was a "contract among Yugoslav peoples" (Provisional National Assembly, 1945, p. 57), but would not go as far as to state it was formally constitutional.

What Rodoljub Čolaković had to say in the same Parliament on August 21, 1945 is of additional importance: "enemies of the federation often flaunt with arguments on how the federation endangers the security and fate of the Serbian nation in Yugoslavia. I should wish to speak as a Serb from outside Serbia... How can we adopt the constitution of new Yugoslavia, if in the assembly adopting the constitution all federal units are not represented at par [as expressed in decisions of AVNOJ itself]"? (Provisional National Assembly, 1945, p. 165). "We in Bosnia and Herzegovina, particularly targeted by reactionaries speaking about the fragmentation of Serbia, declare that we, Serbs in Bosnia and Herzegovina, were the promoters of federation" (Provisional National Assembly, 1945, p.166).

\section{AVNOJ principles in the political life of Tito's Yugoslavia}

This Decree would become the most important pillar in the organization of Yugoslavia not only ideologically but constitutionally. During the existence of that state, the 
AVNOJ Decree and even "AVNOJ principles" would be invoked ceaselessly by those demanding more "states' rights «, equally as those calling for a stronger federal government. It also set certain limits in institutional arrangement and political practice. For example, in 1949, Aleksandar Rankovićs Secretariat of the Yugoslav Communist Party Central Committee proposed the introduction of a new level of government, the "regions", by way of which the federal government would be able to bypass the republics in implementing its decisions. Miha Marinko, a Slovenian communist leader, vetoed the proposal at the Central Committee session. No such proposal was ever attempted (Petranović, Končar and Radović, 1985, pp. 214-219). Of course, later, when republics became more empowered, such interventions, as by Marinko, were not necessary.

An unusual instance of the limitation of invoking AVNOJ principles arose before the 1971 population census, when there was an initiative to allow self-expression as being of Yugoslav identity to be entered as an official option of national identification. Tito initially supported the initiative. It took two emissaries of the Party leadership, the Slovene Vida Tomšič and the Macedonian Krste Crvenkovski, to convince Tito that it was official only that Yugoslavia was composed of six nations. (Simić, 2004, p. 285).

This was the time when Crvenkovski advanced bold ideas of Yugoslav citizenship being considered only a derivative of republic citizenship (which would be accepted, leading to republics disposing with registers of citizenship records at the time of dissolution) and of doing away with the judiciary at the federal level (Flere and Klanjšek, 2017, p. 200).

Within the leadership, AVNOJ set limits to both overstepping republic autonomy (particularly in the early period) and to dissolving the federal state (particularly in the early 1970s).

\section{Historical issues concerning the Yugoslav republics Constitution}

There is no doubt that communist leaders did want the contents of the Decree, although there were significant disagreements during the discussion needing to be noted, prior to its - let us say - adoption. One certainly cannot say that they were simply undertaking gerrymandering (Connor, 1984, p. 333) or that they took the issue of the number of units and their borders lightly as Brubaker (1996, p. 6) would have it. Communists were very respectful of their ideological credo, which contained a firm stand on the issue of national self-determination, although these issues were debatable.

Historical conditions, as well as uncertainties as to ethnic groups and identities, had to be considered. The national groups recognized by the communists were: Croats, Macedonians, Montenegrins, Serbs and Slovenes and Boniaks/Muslims in a de facto way. Also, the population was ethnically mixed geographically. However, Đilas, who was most involved in the issue, testified that the decisions were taken »facilely (interview in Politika, 1992), probably owing to the general euphoria of triumph. However, this may be impressionistic, meaning the disagreements were not dramatically expressed, and in contrast to the dramatic events he was yet to face of confrontation with Stalin and his own expulsion from the leadership.

The communists were, according to their previously established political tenets, obligated to establish Macedonia, if not to extend its full independence. In the context of realistic politics, it was not possible to do otherwise, as their leader Metodija Andonov 
Ćento and others were fighting only for Macedonia and particularly for Greater Macedonia, including Aegean Macedonia.

Bosnia and Herzegovina was the major bone of contention, as mentioned, although there were others (Sandžak, Dalmatia, Dubrovnik and Vojvodina). Kosovo would prove itself to be a different type of problem. Bosnia and Herzegovina could have been partitioned between Croatia and Serbia or appended to one of them solely. From direct data, we know that the Croatian Partisan leader Andrija Hebrang having established Croatian Communist Party cells in Bosnia during the War indicated the intention of establishing Greater Croatia. On the other hand, Serbian communist leaders Moša Pijade and Sreten Žujović, supreme command members, not only claimed Bosnia and Herzegovina as Serbian land, but also proclaimed that, should Bosnia and Herzegovina or Vojvodina attain the federal status "Serbia [Serbs] would not fight" in the forthcoming campaign to force Nazi forces out of Serbia (Končar and Boarov, 2011, p. 102-103), presuming that Bosnia and Herzegovina would be a part of Serbia.

It is difficult to say to what extent the decision to establish Bosnia and Herzegovina was adopted as a step to overcome Serbian and Croatian claims and to what extent it was a step towards enabling full national constitution of Bosniaks (designated Muslims at the time). The latter argument was certainly also present. The main ideologue for the Muslims/ Bosniaks among the communists, Avdo Humo, wrote "Bosnian Muslims are yet at the beginning of national constitution" (Tito et al, 1945, p. 68). Certainly, Bosniaks were most interested in attaining a republic, but support from Rodoljub Čolaković, a Serbian party veteran, and other leading Serbian communists, may have been decisive, although at the time Muslims/Bosniaks were less numerous than Serbs in Bosnia and Herzegovina itself.

Vojvodina was promised federal status in Tito's 1936 "Letter for Serbia" (Tito, 1982, pp. 3, 37), but it lost its national complexity after the expulsion of Germans at the end of the War, and Serbs attained a slight absolute majority ( $51 \%$ by the 1948 Population Census, Miljković 1989, p. 49). In contrast to this objective fact, the Vojvodina historian Končar opined that subjective reasons were decisive in the failure. Some Vojvodina communist leaders had fallen (Žarko Zrenjanin, for example), others, particularly Jovan Veselinov did not work to this end, (Končar and Boarov, 2011). There were disputes about Vojvodina: Đilas held that Hebrang "strongly« claimed Croatia extended as far as »Zemun « (Đilas, 1983, p. 99), which would amount to claiming all of Srem/Syrmia. Another part of historical Vojvodina was empirically surveyed by a committee chaired by Đilas as to establish its ethnic composition. The finding was not applied quite literally: Baranja would become part of Croatia, in spite of Serbian islands within it, and Subotica, with a slight Croatian majority, would remain in Serbian Vojvodina. Serbs were a slight majority in Vukovar, but it remained in Croatia. Entire regions would be taken as criterion. "Alien" population remained both in future Croatia and in Serbia (Petranović 1990, p. 697).

Sandžak, which declared itself a "land" (code name for federal entity) prior to the Second Session and established a land council at the time, would not be granted the status of a republic or even autonomy. It was to be partitioned between Serbia and Montenegro, although both claimed it in entirety. The deliberation took place at the AVNOJ Presidency Session as late as February 24, 1945. The discussion was substantive, a dispute arising on the proposal not to grant it any status and to partition it between Serbia and Montenegro. Marko Vujačić demanded that Sandžak, along with Kosovo and Metohija, become part of 
Montenegro in entirety (Nešović, 1951, p. 54). No one else sided with him, but various reservations were expressed about the proposal of Sandžak being done away with as an entity of any kind. Sreten Vukosavljević demanded time and consultation (Nešović, 1951, p. 55), although one can presume he would have favored making the entire region part of Serbia. At the end, there was no contest as to the adoption of what Pijade and Kardelj, the two present AVNOJ i.e. National Committee vice-presidents, held: Sandžak did not attain an official status; it was partitioned because of the absence of an economic and, as the AVNOJ Presidency held in February, 1945 would stress - "a national basis" (Nešović, 1951, pp. 51$60)$. It was not composed of a single nation. Its land council would dissolve itself.

This is because Sandžak has historically been an ethnically mixed region, composed mainly of Orthodox Serbs and Bosniaks/Muslims. The Berlin Congress agreement provided it with a special status. Although it was not part of Bosnia and Herzegovina, AustriaHungary was allowed to hold some troups there. At the time, it remained within the Ottoman Empire and would be taken over by Serbia and Montenegro during the First Balkan War. Granting it a land status would have practically meant introducing a second major exception, along with Bosnia and Herzegovina, as to observing the nationality principle. Interestingly, the Sandžak Land Council was established by consensus among some Serbs and Bosniaks, but the major reason, according to Petranović, who can be trusted in this respect "was the fear of Serbs on the part of Muslims" (Petranović, 1990, p. 566).

Kosovo may have been the hardest to deal with, since there was an anti-Partisan, antiYugoslav Albanian insurrection going on in 1944-5. Albanians formed the absolute majority in the region and were burdened by a long history of hardship under the Serbs, which the Yugoslav CP acknowledged. Although mentioned many a time (see Petranović, 1991), a unification with Albania was never really on the table as a proposal (which would have resolved the issue by making Kosovo part of the Albanian unit within Yugoslavia). According to Petranović, the meeting of the Yugoslav communist leadership in which the decision on the region's status was taken, was held in April 1945, with a Serbian (Blagoje Nešković) and two Kosovo representatives invited (Fadil Hoxha and Miladin Popović). The Kosovo representatives (an Albanian and a Serb) were both hopeful for a federal unit (practically impossible, since federal units were declared on 24 February 1945), whereas the Serbian representative would cede only a district status (nothing more than an administrative unit). This was in line with the Serbian view of Kosovo being not only an important part of Serbia, but also its cradle and the place of greatest symbolic value. Partitioning Kosovo (and Metohija) between Serbia, Macedonia and Montenegro was also considered. The decision was to grant Kosovo autonomy within Serbia, although lesser in extent than that of Vojvodina (Petranović, 1991, p. 104). This meeting and this decision could well have taken place after the Decree was published, as there were no Kosovo representatives at the session and particularly since Kosovo gaining the status of a republic was not an option.

\section{Issues involving the authenticity of the Decree}

Nevertheless, it is highly questionable whether the Decree on federal arrangement was adopted that night. In fact, there are very strong indications to the contrary.

The Politburo of the Communist Party of Yugoslavia met two weeks prior to the Second Session, laying down the political platform. It called for AVNOJ to adopt a slogan 
"to underscore the propaganda slogan of federation of South Slavs, also to be presented to Greek and Albanian people” (Petranović and Zečević, 1988, p. 636).

This means that at the time the narrative was more propagandistic in nature than a constitutional draft.

After the Second Session, Tito informed the Soviet Government of the Session, making no mention of federal organization. On the basis of their missions with the Partisan headquarters, the US and British allies were also informed and they commented. Cordell Hull, the U.S. Secretary of State and Anthony Eden, the British Foreign Minister, in their statements about the Session made no mention of the type of future government. However, the Soviet Government mentioned "the federal principle" to be applied, although not mentioning any details, particularly not a concrete decision having been taken (Petranović

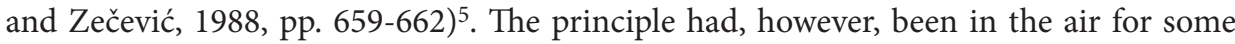
time and was in fact supported by certain parties before the outbreak of War (the Democratic Party and the Peasant Party (Koštunica and Čavoški, 2011, pp. 423-434). Immediately after the Second Session, the three major allies commented on the Session in various ways. Hence, there is no trace of acquaintance with such a decision or even of Tito's report.

As to indications casting doubt on the authenticity we note:

Firstly, as noted, the CPY Politburo met from October $16^{\text {th }}$ to the $18^{\text {th }}$, in preparation for the Second Session, and its minutes contain a decision on launching a slogan about the federal arrangement, but nothing more (Petranović and Zečević, 1988, p. 681).

Secondly, the official presentation of the Second Session, when accounting for the alleged adoption of the Decree at issue, notes nothing about a discussion, nothing about voting, nor "passing by acclamation", as in the case of other decisions passed, only a "tumultuous applause", a reaction more appropriate for the launching of a slogan (Pijade and Nešović, 1973, p. 238).

Thirdly, Đilas wrote that the decision for Bosnia and Herzegovina to be granted federal status was taken in an informal situation, during a march in the beginning of 1944 . The Serbs and Muslims/Bosniaks from Bosnia had been lobbying for such a decision since November 1943 at least.

The decision-making most probably went informally: Aleksandar Ranković, Tito's deputy and the number one among Serbian communists, said the Bosnian leadership proposed a republic for themselves. Tito agreed, and „to everyone it seemed self-evident and understandable "(Đilas, 1980, p. 356). This was most probably all what was needed for the technical drafting of the Decree. Ranković confirmed the sum of previous discussions. His words were a form of Serbian consent. He was second in command but would usually keep to interrogating prisoners and setting the foundations for his future police empire, without engaging in political discussions.

\footnotetext{
5 The Soviet reference may have to do with their own policy: the Soviet Government sent a missionary to the Partisan headquarters, a Bulgarian communist by the name of Šterju Atanasov. The Soviet government also made a vague suggestion of establishing a federation including Yugoslavia and Bulgaria at the time (November, 1943) (Petranović and Zečević, 1988, p. 635). These editors consider Tito had no intention of complying with Soviet suggestions. The editors consider the true author of the idea of Yugoslav-Bulgarian federation to be Georgi Dimitrov, the former Comintern head, who was prepared in Moscow to head Bulgaria, and wished to boost an anti-Axis movement in Bulgaria (Petranović and Zečević, 1988, pp. 640-641).
} 
Fourthly, Slovenski Poročevalec $(2,1944)$, the journal of the Slovenian Partisan Movement (Liberation Front) devoted an entire issue to the Second Session. A more elaborate article on decisions made was signed by Boris Kidrič, one of the foremost Partisan and communist leaders in Slovenia. It referred to the fact that Yugoslavia was established as a federation of 5 members, designating their names, not mentioning Bosnia and Herzegovina. Kidrič repeated the issue of 5 members in the text, which was fully compatible with Đilas' contention that Bosnia and Herzegovina had not been established at that moment.

In the same issue of Slovenski Poročevalec, the composition of the National Committee was presented. Mile Peruničić, active in the Sandžak Land Council, was named the Sandžak commander (Slovenski poročevalec, 9), not noting the Land Council ${ }^{6}$.

Fifthly, in the archival material we find that on November $30^{\text {th }}$ the AVNOJ Presidency addressed the "patriotic sons and daughters of Serbia and Croatia, Slovenia and Montenegro, Bosnia and Herzegovina, Macedonia, Vojvodina and Sandžak" in same manner (Nešović and Petranović, 1983, pp. 454-455), which is an enumeration of all these regions on the basis of equality. Dalmatia, however, was not mentioned.

Sixthly, Jovan Veselinov, a leader in Vojvodina, in his memoirs referred to popularizing the establishment of the National Committee after the Second Session, but he did not mention a federation (Veselinov, 1980, pp. 13-40).

Seventhly, variations in the enumeration of entities are to be found in AVNOJ legislative drafts, the committee having met on Rog, Slovenia, after the Second Session. For example, in the legislative draft on the state coat of arms, Vojvodina and Sandžak are also mentioned as federation members. This is to have been drawn up early in 1944 (Pijade and Nešović, 1973, p. 273).

Eighthly, there is an inconsistency in the Decree, an illogical variance between points 2 and 3 of the Decree (see Appendix). If there had been reason to establish Sandžak Land Council during the War, and it was considered so according to sound principles, why should it not have been reconfirmed in peace time, as it was to all others. The wording of the Decree does not offer a satisfactory answer, indicating the fact that Sandžak established the council in a situation of poor communication after Tito called for the establishment of local, district and land councils in 1943. They responded in an ambitious way.

Ninthly, during the Second Session in Macedonia there were no "Initiative Committees" referred to in the Decree, (for example, Đilas, 1990, pp. 320). Macedonian Partisans were guided by the idea of their own state only and had no confidence in any Yugoslavia, according to Đilas, at the time, "owing to the long-lasting crude military rule by Greater Serbian chauvinists", but there was at the time hope expressed "that the Macedonian people will yet open their hearts", (Vujošević, 1986, pp. 14, 85).

Only on June, 24th of the following year would the National Committee order the establishment and convocation of the National Liberation Land Council to representatives

${ }^{6}$ As the Slovene political public was, by way of Slovenski Poročevalec, informed only of five established republics and as the decision on granting Bosnia and Herzegovina the federal status was factually taken in January 1944, as Đilas wrote, Rodoljub Čolaković appeared at the First Session of the Slovene National Liberation Council in February, 1944 and "transmitted greetings of the people of Bosnia and Herzegovina”. (First and Second meetings, 1993, p. 38). In this way, the status gained a sort of official nature, whereas Sandžak, also having established a Land Council, was not mentioned. 
of an Initiative Committee established directly prior to this National Committee session and for a particular purpose (Tito 1984: 20, 241-3). It would meet soon, on 2 August 1944 (Petranović and Zečević, 1988, pp. 671-672; Petranović, 1991, 111-112).

\section{Discussion}

This examination more than establishes the document's dating as suspicious. It was practically impossible that it was adopted at the Second Session. However, it was very expedient to have it on the table in 1945 when confronting and politically mastering the »bourgeois « opposition in the Provisional and Constitutional Parliament ${ }^{7}$ (and also popularizing the idea among the general population). It meant holding a sacred constitutional document. In fact, it could be considered »supra-constitutional «, because of the exceptional, extraordinary situation in which it was said to have been adopted. In fact, Kardelj mentioned it as a »compact«. In the Provisional Parliament in August 1945, he stated enthusiastically: "AVNOJ is something more (than a determination for national parity in Yugoslavia). It is a compact between our nations, who - by arms - paved the way to meet in Jajce in a united manner" (Provisional National Assembly, 1945, 150). The Decree acquired a charismatic aura, invoked in different and even opposing contexts until the Yugoslav dissolution.

The decision needed to be made in such a small circle, as the issue was too hot, too contested and a democratic procedure, even if limited to a communist-dominated parliament, would have been impossible, neither concerning the number of units nor the borders between them. However, the decision makers did not take any revolutionary measures as to "lands" and their borders. Besides giving priority to ethnicity, they also took history into consideration, particularly in case of Bosnia and Herzegovina, which is claimed, by its major historian Mustafa Imamović to have had the same borders since the $11^{\text {th }}$ century, being the oldest borders in the region (Imamović, 1998, p. 10). However, this may not suffice in an age of nations.

The signing of the document could not have happened much earlier than February 24, 1945, when Mile Peruničić (secretary of AVNOJ, along with Čolaković) read the declaration on the borders of the republics at the AVNOJ Presidency, under the same agenda item as the annulment of the Sandžak Land Council (when preparing the delineation of the borders, Sandžak's non-existence needed to have been factually decided upon before the session). The Presidency accepted the declaration tacitly. There was no discussion, in

\footnotetext{
${ }^{7}$ Milan Grol, the leader of the Democratic Party, in the issue of Demokratija, on September 27, 1945, expressed doubt about the national identity of Macedonians and Montenegrins, also stating "the Morava Vardar line was unseverable«. He considered some nationalities "imagined". He also considered Macedonia "a new barrier to the natural and national development of the Morava region people" [usually considered the heartland of Serbia] (Demokratija, 1, 1, 1, 1945), as if considering Macedonians to be something yet inarticulate, undefined. On the other hand, at the Founding Congress of the CP of Serbia, on May 10, 1945, a soldier by the name of Radoje Ljubičić reported that Serbian soldiers from Serbia proper in his unit felt that "Serbia should annex Macedonia, even Montenegro" (Founding Congress of the Communist Party of Serbia, 1972, p. 98). Such opinions could, hence, be heard throughtout the social structure of Serbia. At the same Congress, Đilas stormed that Serbian Partisans in Bosnia were disposed to "kill all Muslims" (Founding Congress of the Communist Party of Serbia, 1972, p. 79) (in vengeance).
} 
contrast to deciding on dissolving the Sandžak Council, where there were major differences. Lesser issues followed (Nešović, 1951, pp. 58-59).

The Second Session did not elaborate on the issue of federation, although it was certainly on everyone's lips. But that was not a deliberative body; conditions were not met, only the idea of a Yugoslav federation was promoted and "tumultuously applauded". The remaining details were not insignificant, as some units needed to be established, others not, some autonomy needed to be granted, and the borders needed to be specified. One can imagine some things having been done differently: Bosnia and Herzegovina could have remained un-established; Vojvodina could have been granted the status of a republic, as promised by Tito. In both cases, however, there were strong reasons for doing as was done: in the Bosnian case, it was the fact that the Partisan central forces were hosted in Bosnia, coinciding with unified Bosnian claim to statehood. This was politically very relevant and expedient at the time, but short of a lasting foundation. In the other case, it was both the process of Vojvodina being less demographically complex and the lack of request on the part of Vojvodinians that led to the resolution.

The decisions on the establishment of republics involved having more republics established than some would have expected (particularly the Serbs), who would have been less than enthusiastic to recognize the national nature of Macedonians, Montenegrins and particularly of Muslims/Bosniaks (issue referred to at the Founding Congress of the CP of Serbia [Founding Congress 1972]). However, Yugoslav communist leaders were not acquainted with the idea of a larger number leading to a balance forwarded later by some political scientists (for example, Filippov et al, 2004, p. 271). These authors also consider that it may generally be better to split at least the major national group into several units. In fact, this was done too: Serbs were to be found in Bosnia and Herzegovina and Croatia (not to mention the less than articulate identity of Montenegrins), and Croats in Bosnia and Herzegovina and in Serbia. In fact, Tito claimed in 1945 at the founding Congress of CP of Serbia that such a split would make Yugoslavia "stronger" and "everyone happier" (Founding Congress, 1972, p. 210). However, this was nothing like a deliberate border manipulation, or gerrymandering. It was an attempt to find borders in a situation marked by an ethnically mixed population. They were not created, as Tito stated on that occasion for "republics to wage wars against each other" (Founding Congress, 1972, p. 213). 
Сергеј Флере ${ }^{1}$

Универзитет у Марибору

Филозофски факултет

Марибор (Словенија)

\title{
АУТЕНТИЧНОСТ ОСНИВАҢА ТИТОВЕ ЈУГОСЛАВИЈЕ КАО ФЕДЕРАЦИЈЕ
}

\author{
(Превоg In Extenso)
}

Апстракт: Широко је прихвађено да је Титова Југославија била институционално утемељена током заседања ABHOJ-a, наиме током Другог заседања Антифашистичког већа народног ослобођења Југославије, одржаног 29. новембра 1943. у босанским шумама. На скупштини је требало да буде усвојена повеља која се тиче федеративне организације. Одлука је садржавала принципе будуће организације Југославије (шест република, заједно са паритетом република и националности). Ни истраживачи ни политичари у бившој земљи и у иностранству нису доводили у питање истинитост тврдње да је декларација усвојена на овом заседању.

Одлука је била инструментална у настојању комуниста да наметну федерацију и комунизам, када су били суочени са предратним политичарима и Прелазном и Уставотворном скупштином, 1945. и 1946. године. Комунисти су могли да тврде касније да је федерализам већ успостављен. Касније, на Одлуку су се нашироко позивали током Титове Југославије, како они који су се залагали за већа „права држава“ тако и они који су тврдили да је Југославија већ била превише децентрализована.

При ближем испитивању, више је него упитно да ли је таква уставна повеља могла да буде усвојена у таквој ситуацији. Многа питања којима се одлука бави била су спорна и предмет коначног одлучивања АВНОЈ-а после Другог заседања (и 1945. године). Технички детаљи такође указују да Одлука није усвојена у том моменту, него да је усвојена у неформалној ситуацији од стране комунистичких вођа неког каснијег датума, али не касније од фебруара 1945. Ипак, Одлука је све време функционисала као извор легитимитета и инструмент за постављање одређених ограничења у политичком животу бивше државе.

Кључне речи: Антифашистичко веће народног ослобођења Југославије (АВНОJ), Јосип Броз Тито, етничка припадност, комунизам.

\footnotetext{
1 sergej.flere@um.si
} 


\section{Историјски увод}

Од самог почетка југословенског партизанског покрета 1941. године, предвођеног комунистима, Тито и вероватно остали су имали идеју да поставе основу грађанске подршке на институционалан начин. То је требало да припреми пут за будуће уређење државе, комунистичке федерације. Већ августа 1941, Тито је размишљао о „народно-ослободилачком одбору” у писму вођама хрватских комуниста, Радету Кончару и Владимиру Поповићу (Petranović 1988 II, 197). Ово је примењено прво на локалном нивоу, мада је већ 1942. године постојао покушај од стране Антифашистичког већа народног ослобођења Југославије (познатог под српско-хрватским акронимом АВНОJ) да одржи „скупштину”. Веселин Маслеша, водећи босански комуниста, рекао је да он „није био технички изабран ... али је био демократскији од свих до сада представничких тела у Југосавији" (Pijade, Nešović, 1973, str. 36). Његов значај је био ограничен, с обзиром да Словенци, поред Македонаца и делегата са Косова и Метохије, нису били присутни. Био је састављен од партизанских вођа и присталица.

После септембра 1943, када је Италија напустила Силе осовине, партизански покрет је задобио даљи залет, укључујући кроз принудну регрутацију. Немачке трупе нису биле у стању да замене италијанске, дајући партизанским снагама подстицај, посебно у западним деловима Југославије. Чак и у Македонији (где претходно ниједна југословенски оријентисана иницијатива није могла да задобије народну подршку), подигао се партизански покрет. Титов изасланик за југ у то време је настојао да придобије Албанце да се придруже партизанским снагама (Petranović, 1991). Партизани су почели да делују као званична снага (мада ће њихово уобличавање у Југословенску армију доћи касније).

Из војног угла, у то време, британска интервенција у Југославији је такође била могућа, што би повећало вероватноћу поновног успостављања старог режима, мада је готово немогуће да би Југославија била поново успостављена као трајна држава на овај начин. Односи у оквиру емигрантске владе пружају доказе који указују у том смеру због оштрих свађа и неспособности да делује (Pavlowitch, 2008, str. 190; Petranović, 1990, str. 506-520). Хобсбаум, Павлович и Банац се сви слажу да су комунисти били једини способни да обнове Југославију (Hobsbawm, 2010, str. 82; Pavlowitch, 2008, str. 280; Banac, 2009).

Пред крај 1943, партизани су били далеко од превласти у војној контроли територије; нацисти и њихови квислинзи су били доминантни широм Југославије. Сами партизани су били далеко од компактне силе (Nikolić, 2015), мада је постојала централна команда на челу са Титом, и такође су централне јединице, у контрасту са локалним, чији чланови нису били спремни да одлазе далеко од својих локалитета. Ово је било нарочито истинито за Словенце. Хебранг, суверени лидер хрватских партизана, стално је наглашавао хрватску природу покрета и критиковао у својим публикацијама трулу природу Југославије као такве, мада су Срби представљали већину његових снага до краја 1943. У самој Србији, након дебакла „Ужичке републике“ 1941. (ослобођена територија у југозападној Србији током 70 дана) и након бруталних немачких репресалија, партизански покрет у Србији је био слаб, чинећи политички положај српских комунистичких вођа Жујовића, Нешковића и Пијаде - такође слабим. 
У Војводини (са изузетком Срема, чији су партизани били повезани са онима из Босне), партизански покрет је био такође слаб. Партизани су већином деловали путем илегалних „база”. На Косову, он је углавном био повезан са албанским партизанским покретом са намером уједињења са њим. Национално непријатељство је спречавало успостављање заједничких српско-албанских снага, мада је било покушаја. У Македонији партизани су били мотивисани пре свега сном о „великој Македонији“ (Nikolić, 2015).

У овом раду, биће разматране околности Другог заседања АВНОJ-а, усвајање, датирање и релевантност докумената за будућу федералну организацију Југославије.

Чак и пре него што је заседање почело, вођене су значајне дискусије. Ђилас извештава да су српске вође, Жујовић, Пијаде и други заступали идеју да се укине монархија; пошто је монархија била најпопуларнија у Србији, одсуство монархије би учинило ситуацију за њихово будуће управљање једноставнијом (Đilas, 1994, str. 43). Други учесници су били више резервисани по овом питању, пошто су били свесни негативне реакције која би дошла од западних савезника и из Совјетског савеза.

Хрватски политичар Божидар Маговац, вођа Сељачке партије, наводно је помињао организовање Југославије као конфедерације (Mršić, 1992, str. 262-5). Ово указује на различитост идеја које су кружиле у Јајцу пре заседања. У време Другог заседања међу комунистичким вођама вођене су расправе о томе како би федерација требало да изгледа (ако уопште):

* Моша Пијаде је заговарао идеју аутономне српске јединице у Хрватској (вероватно у сагласности са Нешковићем ${ }^{2}$ и Жујовићем, вођама Комунистичке партије у Србији ${ }^{3}$, који се не би усудили сами да направе такав предлог), коју су одбацили Ђилас и Тито;

* Словенци су изразили своју одвојеност и захтев да словенске јединице не интервенишу изван Словеније, они су инсистирали и на словенском језику као једином језику командовања, што је Тито потврдио словенској делегацији на Другом заседању за убудуће. Словенци су можда били најсрећнији на Другом заседању пошто су постали „историјски народ“ и „узели своју историју у властите руке”, као што је Јосип Видмар саопштио на Заседању, али је Лола Рибар, вођа комунистичке омладинске организације (СКОЈ) оптужио словеначке партизане за „сепаратизам“ већ априла $1943 .{ }^{4}$ (Documents, 1981, str. 228);

* албански комунисти са Косова и другде примали су команду првенствено од комунистичког вођства у Албанији и били у вези са албанским десничарским организацијама, сви сањајући о „Великој Албанији” као о нечем замисливом (Petranović, 1991);

${ }^{2}$ Нешковић је 1952. избачен из КП због, између осталог, „великосрпског шовинизма“ (Nikolić, 2015, str. 480). Николић такође ово доводи у везу са Нешковићевим ставом према додељивању аутономије Косову 1945.

3 Чак је и Јован Веселинов, један од водећих српских комуниста у послератном периоду, наводно рекао касније у свом животу да су Нешковић и Пијаде били „српски националисти“ (Popović, 2006, III, str. 30).

4 Чак и 1945, словеначка команда је одбила да интервенише у суседној Лици са тадашњим генералштабом Југословенске армије (Križnar, 1987, str. 355). Међутим, 1945. године, словеначке снаге су изгубиле своју аутономију и постале су део Југословенске армије. 
* хрватски комунистички вођа Андрија Хебранг је био потпуно независтан, захтевајући не само Барању, него и Срем и организујући хрватске комунистичке ћелије у босанским градовима, сањајући о „националној држави” (Bilandžić, 2006, str. 447);

* у Македонији ситуација није била артикулисана; партизански покрет је био слаб и сањао о „великој Македонији“. Тито је морао да шаље бројне изасланике. Ставови против Југославије су били тако снажни да је „било које помињање Југославије чинило мобилизацију македонских маса немогућом“ известио је раније Добривоје Радисављевић (Vujošević, 1988, str. 422-423);

* партизански покрети у Босни и Херцеговини и у Санџаку, неочекивано за неке, организовали су своја „земаљска већа“, за разлику од комунистичког учења о националном самоодређењу, пошто су ова два региона била мултиетничка. У оба случаја, суштина је била заштита Бошњака/Муслимана (Petranović, 1990, str. 565, 567);

* српске комунистичке вође нису могле да буду захтевне (пошто би биле оптерећене идиомом „српска хегемонија“). Они, међутим, такође нису могли да буду задовољни „еманципацијом“ Санџака, Босне и Херцеговине, Македоније, Војводине и Црне Горе.

Ова слика може да буде допуњена ситуацијом у емигрантској влади у Лондону, у којој су такође преовладавали етнички спорови, али у том театру имали су „глас“ само Срби, Хрвати и Словенци. Допуњавање ове тројке, дакле, могло је да дода нову равнотежу у односе.

Ђилас ће касније да пише да су комунистички режими постали корумпирани растом национализма (Đilas, 1994), али било је довољно национализма већ у почетку у овом случају, мада ово не значи да није било простора за даље национално „сазревање“. Ми смо дакле суочени са савезом националних покрета, који у суштини нису комунистички, али то јесу у форми, подређени и потиснути у својим екстремним варијантама нарочито од стране самог Тита, уз помоћ Ђиласа, као и уз Кардеља који је такође био користан у овом смислу у своје време.

\section{Заседање}

О току Другог заседања обавештени смо кроз службени приказ Пијаде и Нешовића (Pijade i Nešović, 1973). Приказ је изразито редигован, иако је састанак стенографисан. Неки говори нису представљени у целини (са заградама које су указивале на непотпуност), али нисмо сигурни да је о свему извештено. Пошто је Жујовићев говор објављен, из тога произлази да Хебранг није говорио мада је био присутан, што је тешко да се поверује. Стенограма нема у Архиву Југославије Србије, Словеније или Босне и Херцеговине, и вероватно је бачен после објављивања књиге коју су издали Пијаде и Нешовић 1951. године (1973).

Званична презентација седнице у књизи Пијаде и Нешовића (1973) вероватно је тачна у својем опису високог степена ентузијазма и еуфорије која је била присутна међу делегатима. Ово је потврђено у многим сведочанствима у шестотомној књизи коју су уредили Ђорђевић и Спасић (1963-1973), укључујући нека којима се може веровати (за разлику од других која су била пропагандна). На самом Другом 
заседању, преовладавала је еуфорија, а Љубо Леонтић, старији предратни умерени политичар из Хрватске, назвао је догађај „чудесним“ (Pijade, Nešović, 1973, str. 201).

Заседање је отворио председник Иван Рибар, али главни говор је одржао Тито, којем су следили многи главни комунисти и некомунисти. Углавном, само Заседање је било велика манифестација ентузијазма и јединства, наде и одлучности, мада су говорници говорили као припадници својих националности.

Међу говорницима, после Титовог ентузијастичног говора, следили су Срби. Александар Ранковић је „поздравио“ АВНОЈ у име Комунистичке партије Југославије, Митра Митровић у име Антифашистичког фронта жена (АФЖ), док је Михајло Швабић то учинио у име Комунистичке омладине (СКОЈ). Мијалко Тодоровић, Србин, политички комесар Прве пролетерске бригаде, био је једини који је понудио „националну самокритику“. Он није поменуо српску хегемонију, као што су то учинили неки несрби. Он је рекао да је Србија била „центар реакције“, што се више никада неће догодити. Рекао је да се борба „развија“ у другим областима Југославије, „захваљујући борби [која се претходно] развила у Србији“ (Рijade, Nešović, 1973, str. 162). Дакле, Срби су били добро представљени, али нису имали залеђину националног, антифашистичког земаљског већа.

Поред тога, Сретен Жујовић, српски комунистички вођа, као да је изазивао Тита, тврдио је да Тито неће наћи у Београду, након ослобођења, „базар са великосрпском буржоазијом“, него ће наредна седница АВНОЈ-а бити тамо одржана (Pijade, Nešović, 1973, str. 223). Окрећући се словеначком професионалном војном официру Јаки Авшићу, рекао је да „српски народ никад није престао да се бори“ (Pijade, Nešović, 1973, str. 223). Јака Авшић је рекао „ми, Словенци, били смо истински први који су схватили да смо осуђени на смрт“ (Pijade, Nešović, 1973, str. 204), хрватски комуниста Павле Грегорић се хвалио учешћем „хрватских маса које се у читавој Хрватској придружују партизанском покрету и одлучују о својој судбини“ (Pijade, Nešović, 1973, str. 228) - мада су, у ствари, Срби били ти који су први постали партизани у Хрватској. Марко Вујачић из Црне Горе се хвалио Црногорцима као „борцима са највећом одлучношћу“ (Pijade, Nešović, 1973, str. 164). Чолаковић, вероватно најстарији комуниста, у кратком говору поменуо је Босну и Херцеговину 11 пута, укључујући и то да она више неће да буде „слушкиња“ и залажући се за њен статус републике, мада то није изричито казао (Pijade, Nešović, 1973, str. 220221). Сулејман Филиповић је само могао да каже да су „Муслимани 1941. били међу првима, који су својим резолуцијама осудили злочине“ (Pijade, Nešović, 1973, str. 213). Сви они су дакле говорили као припадници својих нација. Национално-промоциони садржај онога што су говорили био је јасан, покушавајући да представе властите нације у најбољем светлу.

Друго заседање које је трајало само једну ноћ јесте усвојило неке неспорне одлуке: прогласило је себе за највише тело власти у Југославији; установило је „Национални комитет“, врсту владе (којом је председавао Тито); потврдило је титулу Маршалу Титу, такође је установило законодавни комитет који ће да припреми законе за потоње усвајање, на челу са Мошом Пијаде (Dedijer et al., 1972; Petranović, 1989). Све ове резолуције су доступне јавности у Архиву Југославије (Archives of Yugoslavia, n.d.). Друго заседање се није обратило свакој националности појединачно, него њима свима заједно, позивајући их да се придруже борби против 
окупатора, а нарочито позивајући мушкарце да напусте квислинге (практично све војне јединице које су биле активне - а било их је пуно - које нису биле партизанске, сматране су квислинзима).

\section{Одлука и њена релевантност}

У литератури која се бави Титовом комунистичком Југославијом, обично се сматра да је њу установио један готово самозвани парламент, АВНОЈ, на Другом заседању одржаном 29. новембра 1943. Нема спора да је Веће одржало три заседања и да је треће преображено у прелазну скупштину Југославије (интегришући неке предратне посланике и политичаре у последњем кораку), припремајући пут за сазивање комунистички организоване Уставотворне скупштине, која ће усвојити (комунистички федеративни) устав Југославије 31. јануара 1946. Такође, није спорно да је друга седница одржана у Јајцу, у наведено време.

„Делегати” Другог заседања су се срели у ноћи између 29. и 30. новембра 1943. године (Dedijer et al., 1972; Pijade, Nešović, 1973). Ово је неспорно, мада је то био врло тежак и ризичан подухват, с обзиром да су нацисти гонили партизане свугде (на пример, Petranović, 1988, II, str. 280-302; Ramet, 2006, str. 157).

Одлука о организовању Југославије на федералном принципу се обично сматра за главно достигнуће Заседања. Што је најважније, Одлука је пружала гаранције за Југославију састављену од шест република, са једнаким правима и обавезама и са паритетом народности. Она такође побројава „земаљске“ цивилне власти које наводно постоје. Декрет је депонован у Архиву Југославије и састоји се од два листа папира који су пажљиво слепљени, тако да се целокупан садржај уклапа у једну страницу печатирану са „АВНОЈ, СЕКРЕТАРИЈАТ ПРЕДСЕДНИШТВА, БЕОГРАД”, потписану од стране председника и секретара АВНОJ-а. Документ носи број 3 међу документима који су усвојени на Заседању. Међутим, у регистру каталога докумената, у Архиву, пише да је то препис, потписан Новембра 1945. Другим речима, не може да се пронађе оригинал (консултовни су Архиви Србије, Босне и Херцеговине, Словеније и Војни архив).

Било би веома необично за такав декрет, конститутиван по својој природи, да га усвоје у неким босанским шумама, током једне ноћи, „делегати“ који нису изабрани гласањем. Међутим, то није довољно да се искључи ова могућност. Постоји разлог зашто је касније приказан као такав. Било би тешко усвојити такве одлуке у „нормалним“ временима и условима, пошто је било пуно интереса, спорних питања и недоумица. Комунистичким вођама би било далеко лакше да располажу таквим документом, посебно приликом суочавања са „буржоаским“ политичарима, посебно српским.

Али, gа ти су они истиински усвојили „Оялуку о усйостиављьюьу Јуіоставије на

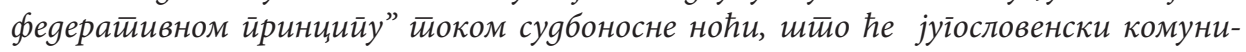

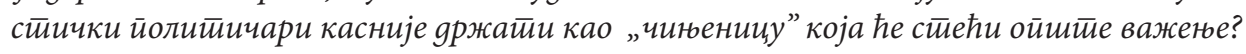
На пример, Едвард Кардељ ће тврдити 10. августа 1945. на Привременој скупштини у својству заменика премијера да »су одлуке Другог заседања уставне по природи ... Данас, Југославија јесте федеративна држава« (Provisional National Assembly, 1945, str. 157), помињући могућност да би то будућа Уставна скупштина могла да проме- 
ни. Он је, такође, коментарисао да је Одлука „уговор међу југословенским народима” (Provisional National Assembly, 1945, str. 57), али није ишао тако далеко да тврди да је Одлука формално уставна.

Додатни значај има оно што Родољуб Чолаковић има да каже у истој Скупштини 21. августа 1945: „непријатељи федерације често машу аргументима како федерација угрожава безбедност и судбину српске нације у Југославији. Ја бих хтео да говорим као Србин изван Србије ... Како можемо да усвојимо устав нове Југославије, ако у скупштини која усваја устав све федеративне јединице нису паритетно представљене [као што је то изражено у одлукама самог АВНОЈ-а]"? (Provisional National Assembly, 1945, str. 165). „Ми у Босни и Херцеговини, који смо нарочито на мети реакционара који говоре о фрагментацији Србије, изјављујемо да смо ми Срби у Босни и Херцеговини били заговорници федерације" (Provisional National Assembly, 1945, str. 166).

\section{Принципи АВНОЈ-а у политичком животу Титове Југославије}

Ова Одлука ће постати најзначајнији стуб у организовању Југославије, не само идеолошки него и уставно. Током постојања те државе, Одлуке АBНОJ-a, па чак и „принципе АВНОЈ-а”, бескрајно су призивали подједнако они који су захтевали више „права република“, као и они који су позивали на снажнију федералну владу. Она је такође поставила извесне іранице у институционалном уређењу и политичкој пракси. На пример, 1949, Секретаријат Централног комитета Комунистичке партије Југославије Александра Ранковића предложио је увођење новог нивоа власти, „области” (региони), путем којих би федерална влада била у могућности да мимоиђе републике у примени својих одлука. Миха Маринко, словеначки комунистички вођа, ставио је вето на овај предлог на седници Централног комитета. Такав предлог никада више није покушан (Petranović, Končar, Radović, 1985, str. 214219). Свакако, касније, када су републике биле оснажене, такве интервенције, какву је уприличио Маринко, више нису биле неопходне.

Необичан пример ограничености позивања на принципе АВНОJ-а појавио се пред попис становништва 1971, када је постојала иницијатива да се дозволи да изражавање југословенског идентитета буде унето као званична опција националне идентификације. Тито је првобитно подржао иницијативу. Два емисара партијског вођства, Словенка Вида Томшић и Македонац Крсте Црвенковски, била су неопходна да би убедили Тита да је једино званично да је Југославија састављена од шест нација (Simić, 2004, str. 285).

То је било време када је Црвенковски заступао храбре идеје да се југословенско држављанство сматра само дериватом републичког држављанства (што је касније усвојено, доводећи до тога да републике располажу регистрима држављанстава у време распада), као и идеје о елиминацији судства на федералном нивоу (Flere, Klanjšek, 2017, str. 200).

У оквиру руководства, АВНОЈ је поставио границе како прекорачењу републичке аутономије (нарочито у раном периоду), тако и растварању федералне државе (нарочито у раним седамдесетим). 


\section{Историјска питања која се тичу \\ Устава југословенских република}

Нема сумње да су комунистички лидери желели садржај Одлуке, мада су постојала значајна неслагања током дискусије које треба споменути и које су постојале пре њеног - рецимо - усвајања. Сигурно не можемо да кажемо да су се они једноставно бавили прекрајањем граница (Connor, 1984, str. 333) нити да су узимали питање броја јединица и њихових граница олако као што Брубакер (Brubaker, 1996, str. 6) сугерише. Комунисти су веома ценили свој идеолошки кредо, који је садржавао чврсто становиште о питању националног самоодређења, мада се о овом питању водила расправа.

Историјски услови, као и несигурности у вези са етничким групама и идентитетима, морали су да буду узети у обзир. Националне групе које су препознавали комунисти су биле: Хрвати, Македонци, Црногорци, Срби, Словенци и Бошњаци/ de facto Муслимани. Такође, становништво је било географски помешано. Међутим, Ђилас који се највише бавио овим питањем сведочи да су одлуке доношене „олако“ (интервју Politika, 1992), вероватно због опште еуфорије тријумфа. Међутим, ово је можда само утисак, који значи да неслагања нису била драматично изражена, за разлику од драматичних догађаја са којима је тек требало да се суочи приликом суочавања са Стаљином и с властитим избацивањем из руководства.

Комунисти су били, према претходно установљеним политичким тезама, обавезни да установе Македонију, ако не и да јој признају потпуну независност. У контексту реалне политике, није било могуће да се учини друкчије, пошто су се њихов вођа Методије Андонов Ћенто и други борили само за Македонију и нарочито за Велику Македонију, укључујући Егејску Македонију.

Босна и Херцеговина је била главна коска спорења, као што је поменуто, мада је било и других (Санџак, Далмација, Дубровник и Војводина). Показаће се да је Косово различит тип проблема. Босна и Херцеговина је могла да буде подељена између Хрватске и Србије или придодата само једној од њих. Из директних података, ми знамо да је хрватски партизански вођа Андрија Хебранг оснивањем ћелија хрватске Комунистичке партије у Босни за време рата наговештавао намеру успостављања велике Хрватске. С друге стране, српске комунистичке вође Моша Пијаде и Сретен Жујовић, чланови врховне команде, не само да су тврдили да је Босна и Херцеговина српска земља, него су такође прокламовали да уколико би Босна и Херцеговина или Војводина стекле федерални статус „Србија [Срби] се не би борили” у предстојећој кампањи избацивања нацистичких снага из Србије (Končar, Boarov, 2011, str. 102-103), претпостављајући да ће Босна и Херцеговина бити део Србије.

Тешко је рећи у којој мери је одлука да се успостави Босна и Херцеговина донета као корак ка превазилажењу српских и хрватских претензија, а у којој мери је то био корак према омогућавању потпуног националног конституисања Бошњака (означених као Муслимани у то време). Овај други аргумент је сигурно такође био присутан. Главни идеолог за Муслимане /Бошњаке међу комунистима, Авдо Хумо, написао је да „Босански муслимани су и даље на почетку националног конституисања” (Tito et al, 1945, str. 68). Јасно, Бошњаци су били веома заинтересовани да стекну 
републику, али подршка Родољуба Чолаковића, српског партијског ветерана, и других водећих српских комуниста, вероватно је била одлучујућа, мада су у то време Муслимани/Бошњаци били мање бројни од Срба у самој Босни и Херцеговини.

Војводини је обећан федерални статус у Титовом „Писму за Србију“ из 1936. [Tito, 1982, str. 3, 37), али је она изгубила националну сложеност после прогона Немаца крајем Рата, тако да су Срби достигли малу апсолутну већину (51\% према Попису становништва из 1948, Miljković, 1989, str. 49). За разлику од ове објективне чињенице, војвођански историчар Кончар сматра да су субјективни разлози били одлучујући за неуспех. Меки војвођански комунистички лидери су пали (Жарко Зрењанин, на пример), други, нарочито Јован Веселинов, нису радили на овом циљу (Končar, Boarov, 2011). Било је спорова око Војводине: Ђилас је сматрао да је Хебранг „снажно“тврдио да се хрватска протеже све до Земуна (Đilas, 1983, str. 99), што би значило својатање читавог Срема. Други део историјске Војводине је емпиријски анкетиран од стране комитета којим је председавао Ђилас како би се установио његов етнички састав. Налаз није примењен потуно дословно: Барања је постала део Хрватске, упркос српским острвима у оквиру ње, а Суботица, са малом хрватском већином, остала је у српској Војводини. Срби су имали незнатну већину у Вуковару, али он је остао у Хрватској. Читави региони су били узети у обзир као критеријум. „Страно” становништво је остало како у будућој Хрватској тако и у Србији (Petranović, 1990, str. 697).

Санџак, који се изјаснио као „земља” (шифровано име за федерални ентитет) пре Другог заседања и који је успоставио земаљско веће у то време, није добио статус републике нити пак аутономију. Биће подељен између Србије и Црне Горе, мада су га обе својатале у целини. Одлучивање се одвијало на седници председништва АВНОЈ-а тек 24. фебруара 1945. Дискусија је била суштинска, а спор је настао поводом предлога да му се не додели било који статус и да се подели између Србије и Црне Горе. Марко Вујачић је тражио да Санџак, заједно са Косовом и Метохојим, постане део Црне Горе у целини (Nešović, 1951, str. 54). Нико није стао на његову страну, али су изражене различите резерве о предлогу да Санџак буде решен као ентитет било које врсте. Сретен Вукосављевић је тражио време и консултације (Nešović, 1951, str. 55), мада се може претпоставити да би он преферирао да целокупни регион учини делом Србије. На крају није било сукоба око прихватања онога што су сматрали Пијаде и Кардељ, два присутна потпредседника АВНОЈ-а, т.j. Националног комитета: Санџак није стекао службени статус; подељен је пошто није било економске и, као што је председништво АВНОЈ-а нагласило у фебруару 1945. - „националне основе” (Nešović, 1951, str. 51-60). Он није био састављен од једне нације. Његов земаљски савет ће се сам распустити.

Ово је зато што је Санџак историјски био етнички мешовит регион, састављен од углавном православних Срба и Бошњака/Муслимана. Споразум Берлинског конгреса му је обезбедио специјални статус. Мада није био део Босне и Херцеговине, Аустроугарској је било дозвољено да тамо држи неке трупе. У то време, остао је у оквиру Отоманске империје, а преузеће га Србија и Црна Гора током Првог балканског рата. Додељивање статуса земље би практично значило прављење другог великог изузетка, поред Босне и Херцеговине, с обзиром на поштовање националног принципа. Оно што је интересантно, Санџачко земаљско веће је успостављено на основу сагласности међу неким Србима и Бошњацима, али главни разлог, према 
Петрановићу, којем се може веровати у овом погледу, „био је страх од Срба од стране Муслимана" (Petranović, 1990, str. 566).

Косово је можда било најтеже за решавање с обзиром да је тамо постојала антипартизанска, антијугословенска албанска побуна током 1944-45. Албанци су представљали апсолутну већину у региону и били су оптерећени дугом историјом тешкоћа под Србима, које је југословенска КП признавала. Иако много пута споменуто (види Petranović, 1991), уједињење са Албанијом није никада било збиља на столу као предлог (који би решио питање учинивши Косово делом албанске јединице у оквиру Југославије). Према Петрановићу, сусрет југословенског комунистичког руководства на којем је донета одлука о статусу региона, на који су позвани један српски (Благоје Нешковић) и два косовска представника (Фадил Хоџа и Миладин Поповић), одржан је априла 1945. Представници Косова (један Албанац и један Србин) надали су се федералној јединици (практично немогуће, зато што су федералне јединице биле декларисане 24. фебруара 1945), док би српски представник доделио само статус области (ништа више од једне административне јединице). Ово је било у складу са српским виђењем Косова као не само важног дела Србије, него и као колевке и места од највећег симболичког значења. Подела Косова (и Метохије) између Србије, Македоније и Црне Горе је била такође разматрана. Донета је одлука да се Косову додели аутономија у оквиру Србије, мада мања него у Војводини (Petranović, 1991, str. 104). Овај састанак и ова одлука су се вероватно десили после објављивања Одлуке, пошто на седници и није било представника Косова и нарочито зато што додела статуса републике Косову није била опција.

\section{Питања која се тичу аутентичности Одлуке}

Међутим, врло је упитно да ли је Одлука о федералном уређењу усвојена те ноћи. У ствари, постоје снажне индиције да није.

Политбиро Комунистичке партије Југославије се састао две недеље пре Другог заседања АВНОЈ-а, постављајући политичку платформу. Позивао је да АВНОЈ усвоји слоган „да се подвуче пропагандни слоган федерације Јужних Словена, који такође треба да се представи грчком и албанском народу“ (Petranović, Zečević, 1988, str. 636).

Ово значи да је у то време наратив по својој природи био више пропагандни него уставни нацрт.

После Другог заседања, Тито је обавестио Совјетску владу о заседању, не помињући федерално уређење. На основу својих мисија при партизанском штабу, САД и британски савезници су такође били обавештени и они ће коментарисати. Кордел Хал, државни секретар САД и Ентони Идн, британски министар спољних послова, у својим изјавама о заседању, не помињу тип будућег уређења. Ипак, совјетска влада спомиње „федерални принцип“ који ће бити примењен, мада без детаља, нарочито не конкретних одлука које су донете (Petranović, Zečević, 1988, str. 659-662) 5 . Принцип је, међутим, био у ваздуху већ неко време и подржале су

${ }^{5}$ Совјетске референце вероватно имају везе са њиховом властитом политиком: совјетска влада је послала изасланика у партизански штаб, бугарског комунисту који се звао Штерју Атанасов. Совјетска влада је такође дала нејасну сугестију о успостављању федерације која би укључивала тадашњу Југославију и Бугарску (новембар 1943) (Petranović, Zečević, 1988, 
га одређене странке пре избијања Другог светског рата - Демократска партија и Сељачка странка (Koštunica, Čavoški, 2011, str. 423-434). Непосредно после Другог заседања, три главна савезника су коментарисала заседање на различите начине. Отуда, не постоји траг о познавању такве одлуке, чак ни Титов извештај.

С обзиром на индиције које бацају сумњу на аутентичност ми напомињемо:

Прво, као што је поменуто, Политбиро КПЈ се састао од 16. до 18. октобра да би припремио Друго заседање АВНОЈ-а и његове забелешке садрже одлуку да се лансира слоган о федералном уређењу, али ништа више (Petranović, Zečević, 1988, str. 681).

Друго, званична презентација Другог заседања, при опису наводног усвајања Одлуке у питању, ништа не помиње о дискусији, ништа о гласању, нити о „усвајању путем акламације“, као у случају других донетих одлука, већ само „громки аплауз“, реакција која је примеренија покретању слогана (Pijade, Nešović, 1973, str. 238).

Tреће, Ђилас је написао да је одлука да Босна и Херцеговина добије федерални статус донета у неформалној ситуацији, током марша почетком 1944, Срби и Муслимани/Бошњаци из Босне су лобирали за такву одлуку најмање од новембра 1943.

Одлучивање је највероватније спровођено неформално: Александар Ранковић, Титов помоћник и број један међу српским комунистима, рекао је да је босанско руководство предложило републику за себе. Тито се сложио и „свима је то изгледало самоевидентно и разумљиво“ (Đilas, 1980, str. 356). Ово је највероватније било све што је потребно за технички нацрт Одлуке. Ранковић је потврдио резиме претходних дискусија. Његове речи су биле облик саглашавања Срба. Он је био други у команди, али се обично држао испитивања затвореника и постављања темеља за своју будућу полицијску империју, без укључивања у политичке дискусије.

Четврто, Slovenski Poročevalec (2, 1944), часопис словеначког партизанског покрета (Osvobodilna fronta) посветио је једно читаво издање Другом заседању. Развијенији чланак о донетим одлукама на Другом заседању потписао је Борис Кидрич, један од водећих партизанских и комунистичких вођа у Словенији. Он помиње да је Југославија установљена као федерација пет чланица, наводећи њихова имена, непомињући Босну и Херцеговину. Кидрич понавља питање пет чланица у тексту, што је у пуној сагласности са тврдњом Ђиласа да Босна и Херцеговина није била установљена у том моменту.

У истом издању листа Slovenski Poročevalec, представљен је састав Националног комитета. Миле Перунчић, активан у Земаљском већу Санџака, именован је за команданта Санџака (Slovenski poročevalec, 9), без помињања Земаљског већа ${ }^{6}$.

str. 635). Ови уредници сматрају да Тито није имао намеру да испуни ову совјетску сугестију. Уредници сматрају да је истински аутор идеје о југословенско-бугарској федерацији био Георги Димитров, бивши главешина Коминтерне, који је био припреман у Москви да управља Бугарском, па је желео да подстакне покрет против сила осовине у Бугарској (Petranović, Zečević, 1988, str. 640-641).

${ }^{6}$ Пошто је словеначка политичка јавност била обавештена, путем листа Slovenski Poročevalec, само о установљењу пет република и како је одлука о додељивању федералног статуса Босни и Херцеговини фактички донета у јануару 1944, као што је Ђилас написао, Родољуб Чолаковић се појавио на Првом заседању словеначког Националног савета ослобођења у 
Пето, у архивском материјалу ми налазимо да се 30. новембра председништво АВНОЈ-а обратило „патриотским синовима и кћерима Србије и Хрватске, Словеније и Црне Горе и Босне и Херцеговине, Македоније, Војводине и Санџака” на исти начин (Nešović, Petranović, 1983, str. 454-455), што представља набрајање свих ових региона на основу једнакости. Далмација, међутим, није поменута.

Шесто, Јован Веселинов, вођа у Војводини, у својим мемоарима помиње популаризацију успоставања Националног комитета после Другог заседања, али не помиње федерацију (Veselinov, 1980, str. 13-40).

Седмо, постоје варијације у побројавању ентитета у законодавним нацртима ABНОJ-a, када се комитет састао у Рогу, Словенија, после Другог заседања. На пример, у законодавном нацрту државног грба, Војводина и Санџак се такође помињу као чланови федерације. Овај докуменат је наводно написан почетком 1944. године (Pijade, Nešović, 1973, str. 273).

Осмо, постоји неконзистентност у Одлуци, једна нелогична варијација између тачке 2 и тачке 3 Одлуке (види Прилог). Уколико је постојао разлог да се успостави Земаљско веће Санџака током рата, а тако је сматрано према јасним принципима, зашто оно не би било поново потврђено у време мира, као што је то био случај са свима осталима. Формулација Одлуке не нуди задовољавајући одговор, индицирајући да је Санџак успоставио веће у ситуацији слабе комуникације, пошто је Тито позвао на успостављање локалних, обласних и земаљских већа 1943. Они су одговорили на амбициозан начин.

Девето, за време Другог заседања у Македонији није било „иницијативних комитета” који се помињу у Одлуци (на пример, Đilas, 1990, str. 320). Македонски партизани су се руководили једино идејом властите државе и нису имали поверење у било коју Југославију, према Ђиласу, у то време, „због дуготрајне грубе војне управе од стране великосрпских шовиниста”, али је у то време постојала нада „да ће македонски народ још отворити своја срца”, (Vujošević, 1986, str. 14, 85).

Тек 24. јуна наредне године ће Национални комитет наложити успостављање и сазивање Националног земаљског већа ослобођења представницима Иницијативног комитета успостављеног непосредно пре ове седнице Националног комитета с одређеном наменом (Tito, 1984, 20, 241-243). Оно ће се ускоро састати, 2. августа 1944. (Petranović, Zečević 1988, str. 671-672; Petranović. 1991, str.111-112).

\section{Дискусија}

Ово истраживање више него утемељује датирање документа као сумњиво. Практично је немогуће да је усвојен на Другом заседању. Међутим, било је врло корисно имати га на столу 1945. приликом суочавања и политичког савладавања „буржоаске“ опозиције у Привременој и Уставотворној скупштини ${ }^{7}$ (и такође приликом

фебруару 1944. и „пренео поздраве народа Босне и Херцеговине“ (First and Second meetings, 1993, str. 38). На овај начин, статус је стекао једну врсту службене природе, док Санџак, који је такође основао Земаљско веће, није поменут.

7 Милан Грол, вођа Демократске партије, у издању Демократије од 27. септембра 1945, изразио је сумњу о националном идентитету Македонаца и Црногораца, тврдећи такође да „линија Морава Вардар не може да се раздвоји“. Он неке националности сматра „измишљеним”. Он такође сматра Македонију за „нову препреку природном и националном развоју на- 
популаризације идеје међу становништвом генерално). Значио је поседовање светог уставног документа. У ствари, документ би се могао сматрати „надуставним“, због изузетне ванредне ситуације у којој се тврди да је усвојен. Заправо, Кардељ га помиње као „уговор“. У Привременој скупштини он је августа 1945. ентузијастично саопштио: „АВНОЈ је нешто више (него опредељење за нацонални паритет у Југославији). Он је уговор између наших нација, који је - путем оружја - трасирао пут за састанак у Јајцу на уједињени начин" (Provisional National Assembly, 1945, str. 150). Одлука је задобила харизматску ауру, која ће бити призивана у различитим и чак супротним контекстима све до распада Југославије.

Одлука је морала да буде донета у тако малом кругу, пошто је питање било одвише врело, сувише оспоравано и демократска процедура, чак и ако је ограничена на скупштину којом доминирају комунисти, била би немогућа, како у вези са бројем јединица, тако и у вези са границама између њих. Међутим, доносиоци одлуке нису предузели било какве револуционарне мере у односу на „земље“ и њихове границе. Поред давања приоритета етницитету, такође су узимали у обзир и историју, особито у случају Босне и Херцеговине, за коју се тврди од стране њеног главног историчара Мустафе Имамовића да је имала исте границе од једанаестог века, дакле најстарије границе у региону (Imamović, 1998, str. 10). Међутим, ово можда није довољно у добу нација.

Потписивање самог документа није могло да буде много раније од 24. фебруара 1945, када је Миле Перуничић (секретар АВНОЈ-а, заједно са Чолаковићем) прочитао декларацију о границама република на Председништву АВНОJ-а, под истом тачком дневног реда као и распуштање Земаљског већа за Санџак (када је припремано разграничење, непостојање Санџака је требало да буде фактички одлучено пре седнице). Председништво је прихватило декларацију у тишини. Није било дискусије, за разлику од одлучивања о распуштању Већа Санџака, у којој је било значајних разлика. Уследила су мања питања (Nešović, 1951, str. 58-9).

Друго заседање није елаборирало питање федерације, мада је она сигурно била свима на уснама. Међутим, то није било тело одлучивања, услови се нису стекли, само је промовисана идеја југословенске федерације, пропраћене уз „громогласни аплауз“. Преостали детаљи нису били безначајни, с обзиром да је требало да се успоставе неке јединице, а друге не, извесна аутономија је требало да буде призната, и границе је требало спецификовати. Може се замислити да су неке ствари биле урађене на различит начин: Босна и Херцеговина је могла да остане неуспостављена; Војводина је могла да добије статус републике, као што је Тито обећао. У оба случаја, међутим, постојали су снажни разлози да се учини онако како је учињено: у случају

рода Моравског региона“ [који се обично сматра за средиште Србије] (Demokratija, 1, 1, 1, 1945), као да сугерише да је Македонија нешто још неартикулисано, недефинисано. С друге стране, на Оснивачком конгресу КП Србије 10. маја 1945, војник по имену Радоје Љубичић је известио да српски војници из саме Србије у његовој јединици сматрају да би „Србија требало да анектира Македонију, чак и Црну Гору” (Founding Congress of the Communist Party of Serbia, 1972, str. 98). Оваква мишљења су се према томе могла чути кроз све друштвене структуре Србије. На истом Конгресу, Ђилас је нагласио да су српски партизани у Босни били диспонирани да „убију све Муслимане” (Founding Congress of the Communist Party of Serbia, 1972, str. 79) (због освете). 
Босне, то је била чињеница да су централне партизанске снаге биле распоређене у Босни, што је коинцидирало са јединственим захтевом Босне за државношћу. То је било веома релевантно и практично у то време, али није имало трајни темељ. Што се другог случаја тиче, у Војводини је процес био демографски мање сложен, није било довољно захтева Војвођана што је довело до постојећег решења.

Одлука о успостављању република је подразумевала успостављање више република него што би неко очекивао (нарочито Срби), који би били мање него ентузијастични да признају националну природу Македонаца, Црногораца, и нарочито Муслимана/Бошњка (питање које је поменуто на Оснивачком конгресу КП Србије [Founding Congress, 1972]). Међутим, југословенски комунистички лидери нису били упознати са идејом да већи број доводи до равнотеже, као што су то касније изјављивали неки политички научници (на пример, Filippov et al, 2004, str. 271). Ови аутори такође сматрају да је можда генерално боље да се подели барем највећа национална група у више јединица. У ствари, и то је урађено: Срби су се нашли у Босни и Херцеговини и у Хрватској (да не спомињемо мање него артикулисани идентитет Црногораца), а Хрвати у Босни и Херцеговини и у Србији. У ствари, Тито је тврдио 1945. на Оснивачком конгресу КП Србије да ће таква подела учинити Југославију „јачом“, а све „срећнијим“ (Founding Congress, 1972, str. 210). Међутим, ово није било намерно прекрајање граница. То је био покушај да се пронађу границе у ситуацији обележеној етнички мешовитим становништвом. Оне нису створене, како је Тито навео том приликом, да би „републике водиле ратове једна против друге“ (Founding Congress 1972, str. 213).

\section{REFERENCES / ЛИTEPATУPA}

Bilandžić, D. (2006). History Close, memoirs 1945-2005 . Zagreb: Prometej.[In Croatian] Brubaker, R. (1996). Nationalism Reframed: Nationhood and the National Question in the New Europe. Cambridge: Cambridge University Press.

Connor, W. (1984). The National Question in Communist Theory and Strategy. Princeton, NY: Princeton University Press.

Dedijer, V, Ekmečić M, Ćirković S, and Božić I. (1972). History of Yugoslavia. Beograd: Prosveta [In Serbian]

Demokratija. (1945). 1,1,1. [In Serbian]

Documents (1981). Documents of the People's Revolution of Slovenia, vol. 6, document 89. Ljubljana: IZDG [In Slovene]

Đilas, M. (1980). Wartime. New York: Harcourt, Brace and Jovanovich.

Đilas, M. (1983). Rise and Fall. New York, NY: Harcourt, Brace, Jovanovich.

Đilas, M. (1992, September 2). Serbia was not Chetnik. Politika. [In Serbian]

Đilas, M. (1994). The fall of the new class: a history of the self-destruction of communism. Beograd: Službeni list SRJ. [In Serbian]

Đorđević, Ž, Spasić. Ž. (1963-1973). That's how the new Yugoslavia was born: a collection of memories of participants of the Second Session of AVNOJ. Beograd: Kultura [In Serbian] 
Filippov, M, Odershook, P, Shvetsova, O. (2004) Designing Federalism: A Theory of SelfSustainable Federal Institutions. Cambridge: Cambridge University Press.

First and Second meetings of the Slovenian National Liberation Council (1993) Crnomelj, February 19th - 20th 1944 and Ljubljana, 9th and 10th September 1946. Ljubljana: S.n [In Slovene]

Flere, S, Klanjšek, R. (2017). How the ethnic communist elites through the continuity of their strife led to the inevitable collapse of the SFRY. Beograd: Dan Graf. [In Serbian]

Founding Congress of the Communist Party of Serbia, 8-15 May 1945. (1972). Beograd: Komunist [In Serbian]

Hobsbawm, E. (1990). Nations and Nationalism since 1780: Programme, Myth, Reality. Cambridge, MA: Cambridge University Press.

Imamović, I. (1998). History of Bosniaks. Sarajevo: Preporod. [In Bosnian]

Končar, R, Boarov, D. (2011). Stevan Doronjski - defense of the autonomy of Vojvodina. Novi Sad: Mir. [In Serbian]

Koštunica, V, Čavoški, K. (2011). Party pluralism or monism: the renewal and suppression of the post-war opposition, Beograd: Službeni glasnik. [In Serbian]

Križnar, I. (1987). From the revolutionary movement to the institutional forms of the Slovenian state, Ljubljana: Komunist. [In Slovene]

Lampe, J. (2002). Yugoslavia as history: twice there was a country, Cambridge: Cambridge University Press.

Matković, H. (1998), History of Yugoslavia: (1918-1991): Croatian view, Zagreb: Naklada Pavičić. [In Croatian]

Mihailović, K. (1990). Economic reality of Yugoslavia, Beograd: EKONOMIKA. [In Serbian]

Mihailović, K, Krestić, V.. (2002). "SASA Memorandum”: under political strikes, Beograd: Borba. [In Serbian]

Miljković, D. (1989). Yugoslavia: Statistical Yearbook 1918-1988, Beograd: Savremena administracija. [In Serbian]

Mršić, T. (1992). Scientific reports by I. Supek, P. Strčić and L. Boban about Bozidar Magovec at the HASA Conference. In: Z. Grijak (ed.) Historical collection XLV, 1(pp. 262-267). Zagreb: Institut za savremenu povjest [In Croatian]

Nešović, S. (ed, 1951). Legislative work of Presidency of AVNOJ and Presidency of Provisional National Assembly DFY (19th Novembre 1944 - 27th Octobre 1945). Beograd: Prezidijum Narodne skupštine FNRJ

Nešović, S, Petranović, B, (eds.). (1983). AVNOJ and Revolution: Thematic Document Collection 1941-1945, Beograd: Narodna knjiga. [In Serbian]

Nikolić, K. (2015). Myth about Partisan Yugoslavia . Beograd: Zavod za udžbenike. [In Serbian]

Pavlowitch, S, K. (2015). Hitler's new Disorder: The Second World War in Yugoslavia. London: Hurst and Company.

Petranović, B. (1989). History of Yugoslavia, 1918-1988, Beograd: Nolit. [In Serbian]

Petranović, B. (1990). Serbia in the Second World War: 1939-1945, Beograd: Vojnoizdavački zavod. [In Serbian]

Petranović, B. (1991). Balkan Federation 1943-1948. Šabac: Zaslon. [In Serbian] 
Petranović, B, Zečević, M, (eds.). (1988). Yugoslavia: 1918-1988: a thematic collection of documents. Beograd: Biblioteka Svedočanstva. [In Serbian]

Petranović, B, Končar, R, Radonjić, R, (eds.). (1985). Sessions of the Central Committee of the CPY: (1948-1952), (Beograd: Komunist, 1985). [In Serbian]

Pijade, M, Nešović, S, (eds.). (1973). First and Second sessions of AVNOJ: [26 and 27 November 1942 and 29 and 30 November 1943]. Ljubljana: Komunist. [In Slovene]

Pleterski, J. (1985). Nations, Yugoslavia, Revolution. Beograd: Komunist. [In Serbian]

Popović, D. (2006). The Chronicle of Vlaovići, Novi Sad: Mir. [In Serbian]

Provisional National Assembly (1945). Session. Beograd: Prezidijum Narodne skupštine

Ramet, S, P. (2006). The Three Yugoslavias. State Building and Legitimation, 1918-2001. Washington, DC: Woodrow Wilson Publishing Center.

Session of the Constitutional Assembly (1946). Stenographic notes. Beograd: Prezidijum Narodne skupštine. [In Serbian]

Simić, P. (2004). The saint and the fog. Tito and his time in the new documents of Belgrade and Moscow. Beograd: Službeni list SCG. [In Serbian]

Slovenski Poročevalec. 2 (1944). [In Slovene]

Tito, J, B. (1982). Collected Works. Vol. 3. Ljubljana: Komunist. [In Slovene]

Tito, J, B, Đilas, M, Pijade, M, Kardelj, E, Nešković, B, Hebrang, A. (1945). National question II, Zaječar: Tehnika O.K. [In Serbian]

Veselinov, J. (1980). We're all one party, Sremska Mitrovica: Sremske novine. [In Serbian]

Vujošević, R, (ed,1986). Documents of the Central Authorities of the CPY, NOR and the Revolution: (1941-1945). Beograd: Komunist. [In Serbian]

\section{Internet sources}

Archives of Yugoslavia, Available at: www.arhivyu.gov.rs/active/sr-latin/home/glavna_ navigacija/leksikon_jugoslavije/konstitutivni_akti_jugoslavije/deklaracija_drugog_ zasedanja_avnoja.html). [In Serbian]

Kučan, M. (1989, January 30). Yugoslavia can only be democratic, or it will not be (speech); Availableat:http://www2.gov.si/up-rs/2002-2007/bp-mk.nsf/dokumenti/30.01.1989SocRS; Accessed 30 May, 2017 [In Slovene]

Превод на српски / Translation into Serbian

др Вера Вратуша / Vera Vratuša, PhD 
Сергеј Флере, Аутентичност оснивања Титове Југославије као федерације

\section{APPENDIX / ПРИЛОГ}

AHTИФАШИСТКЧKO BËR

HAPO HOF OCJIOBO DEE उYTOCIABMJE

Број одлуке 3

$\begin{array}{llllll}0 & \text { म } & \text { II } & \text { У } & \text { K } & \text { A }\end{array}$

ДРУГОГ ЗАСЕДАНА АНТФФАШССИЧКОГ ВЕКА НАРОДНОГ ОСЛОБОВЕНА ЈУГОСЛАВИЈЕ

Arhiv

- изградњи Југославије на ф্федеративном принципу

Jugoslavije

Beograd

На основу права сваког народа на самоодре ђеве, уклучу јући право на отцепке ие или на уједивене са друтим народима, и у складу с пстинском вољом свих народа Југославије, осведоченом у току трогодишіе заједничке народно-ослободилачке борбе ко ја је сковала нераздрузиво братство народа Југославије, Антисыашисти чко ве ћ̆e народног ослобо је а Југославије доноси следей

$$
0 \text { д }
$$

1. Народи Југославије никада нису признали и не призна.ју раскоманане југослави је са стране фашисти чких импе ри јалиста и доказали су у заједничкој оруваној борби своју чврсту воду да остану и дале у једивени у Југосдавији.

2.Да би се остварио принцип суверености народа Југославије, да би Југославија. претстављала истинску домовину свих својих народа и да никад више не би постала доменом било које хегемонистичке клике, Југославија се изграђу је и изградийе се на седеративном приниилу, који hе обезбедити пуну равноправност Срба, Хрвата, Словенаца, Маке онаца и Црногорача, односно народа Србије, Хрватске, Словеначке, Щакедоније, Црне Горе и Босне и Херцеговине.

3. у складу са таквом федеративном изградњом Југославије, која се теме ии на најпунијим демократским правима, јесте чивеница да већ̆ сада, у време народно-ослободилачког рата, основне органе народне власти код појединих народа Југослави је претстављају народноослоболилачки одбори и земалска внтифашисти чка већа народн ог ослобођења (Главни народно-ослободилачки одбор Србије, Земалчко ан ти таписти чко веће народног ослоборева Хрватске, Словенски народно-осл ободилачки одбор, Земалеко антисапи стйко ве hе народног ослобо је ва Босне

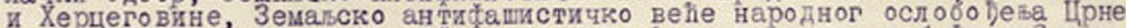
Горе и Боке, Земаљско антифанистичко ве һе народног ослобоle ва Caнџаka. иници јативни органи за Земаљско антйапистичко веће народног ослобо рена Аакедоније), и да је Антифашистйчко вейе народног ослобо ева Југослави је врховно законодавно и извршно претставничко тело народа Југославије и врховни претставник суверенитета народа и дркаве Југославије као целине. наци онална права.

4. Националним мавинама у Југославији обезбедй̄e се сва

5. Ова одлука ступа одмах на снагу.

дне 29 новембра 1943 , y Jajuy

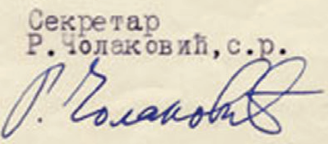

За Антићаш стичко ве Ћ̆е

Народног ослобојена Југославије

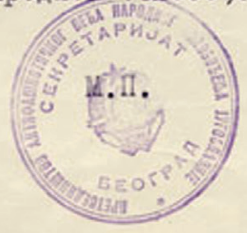

Претседник

Ар.... Рибар, с.p.

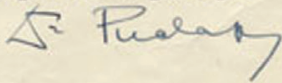


(Translation In Extenso)

\author{
ANTI-FASCIST COUNCIL \\ OF THE NATIONAL LIBERATION \\ OF YUGOSLAVIA \\ Decision no. 3
}

\title{
DECREE OF THE SECOND SESSION OF THE ANTI-FASCIST COUNCIL OF THE NATIONAL LIBERATION OF YUGOSLAVIA
}

On the establishment of Yugoslavia under the federal principle

On the basis of the right of every nation to self-determination, including the right to secede, or to unite with other nations, in compliance with the true will of all nations of Yugoslavia, confirmed in the three-year joint peoples' liberation struggle which has forged an inseparable brotherhood of the nations of Yugoslavia, the Anti-Fascist Council of the National Liberation of Yugoslavia issues the following:

\section{Decree}

1. The nations of Yugoslavia never did recognize and shall not recognize the fragmentation of Yugoslavia by foreign fascist imperialists and they have testified in the joint armed struggle their firm will to remain further united in Yugoslavia.

2. To the end of achieving the principle of sovereignty of nations of Yugoslavia and to the end of Yugoslavia being the true homeland of all its nations and never again becoming the domain of a hegemonist clique, Yugoslavia has been and will be established under the federal principle, which shall secure a full equality of Serbs, Croats, Slovenes, Macedonians and Montenegrins, i.e. the peoples of Serbia, Croatia, Slovenia, Macedonia, Montenegro and Bosnia and Herzegovina.

3. In conformity with such federal establishment of Yugoslavia, founded on the fullest democratic rights, at this time it is already a fact that, during the national liberation struggle, basic bodies of national authorities of certain nations of Yugoslavia are the people's liberation committees and anti-fascist land councils of national liberation (the Main National Liberation Committee of Serbia, the Anti-Fascist Land Council of the National Liberation of Croatia, the Slovene National Liberation Committee, the Anti-Fascist Land Council of the National Liberation of Bosnia and Herzegovina, the Anti-Fascist Land Council of the National Liberation of Montenegro and Boka, the Anti-Fascist Land Council of the National Liberation of Sandžak, and initiative bodies for the Anti-Fascist Land Council of the National Liberation of Macedonia) and that the Anti-Fascist Council of the National Liberation of Yugoslavia is the supreme legislative and executive represen- 
tative body of the nations of Yugoslavia and the supreme representative of the sovereignty of the nations and the state of Yugoslavia as a whole.

4. National minorities in Yugoslavia shall be guaranteed all national rights.

5. This Decree becomes effective immediately.

On November 29th, 1943

In Jajce

On behalf of the Anti-Fascist Council

of the National Liberation of Yugoslavia

Secretary

R. Čolaković (signature)
President

Dr. I. Ribar (signature)

Rubber stamp:

Presidency of the Anti-Fascist Council

of the National Liberation of Yugoslavia, Secretariat, Belgrade 